\title{
MOVING OUT OF CHRONIC POVERTY: COMMUNITY LEVEL STUDY ON POVERTY OVER THE TIME
}

\author{
S. A. N. C. Samaraweera and N. R. Abeynayake
}

\begin{abstract}
In this study poverty is measured as the low level of satisfaction of the ten basic needs and the underutilization of material and non material resources. Further this study explores the economic factors which are related to poverty such as financial capital, physical capital and natural capital (land). The survey was carried out in Wanduressa village which is established by settling down of one of the low caste communities in the country named as Rodiya community. This study was done as close as possible to the base research done Ratnapala, 1979 in same village to compare the current situation. The results indicated that over the time, the community level satisfaction for ten basic needs has increased by $54.95 \%$. According to the satisfaction index constructed, $98 \%$ households obtained satisfaction level above 0.5. Poverty alleviation programmes, awareness programmes and the effort taken by the households to reduce their separation from the high caste communities were the main causes to reduce the poverty over the time. Multiple Linear Regression analysis showed that there is a significant relationship between the satisfaction Index with their income and skills.
\end{abstract}

Keywords: Chronic poverty, Satisfaction level index, Ten basic needs

\section{INTRODUCTION}

The poverty or poor exists where some persons fall short of reasonably defined minimum levels of wellbeing such as access to certain consumption or income levels, housing, health and education facilities and certain rights recognized according to the standards of human needs and socio economic conditions of the society.

The Chronic Poverty Research Centre was established in October 2000 by a group of universities, research institutes, consultancies and NGOs to focus attention on chronic poverty; stimulate national and international debate; deepen understanding of the causes of chronic poverty and to provide research, analysis and policy guidance that will contribute to its reduction. The Chronic Poverty Research Centre is administered by the institute for development policy and management, University of Manchester in UK.

The Chronic Poverty Research Centre defines chronically poor people as those who experience deprivation over many years, often over their entire lives, and who sometimes pass poverty on to their children. Chronic poverty is typically characterized not only by low income

${ }^{1}$ Department of Agribusiness Management, Faculty of Agriculture and Plantation 
and assets, but also by hunger and under nutrition, illiteracy, the lack of access to necessities such as safe drinking water, health services, social isolation and exploitation. Chronically poor people have little access to productive assets and low capabilities in terms of health, education and social capital. They are the invisible poor, and occupy a blind spot when it comes to the design of development policy and the delivery of public services (Anon, 2009b).

In terms of human development indicators, Sri Lanka has been ranked hundred fourth among hundred seventy seven countries (Anon, 2008a). However, $15.2 \%$ of the population of the country has continued to live in poverty. According to the household income and expenditure survey, $2006 / 2007$ conducted by the Department of Census and Statistics in Sri Lanka, 2805 thousands are being poor. Among people below the poverty line, 2303 thousands recorded from rural sector. Poverty head count index is always higher in rural areas with compare to urban areas. It was $29.4 \%$ in $1990 / 1991,30.9 \%$ in $1995 / 1996,24.7 \%$ in 2002 and $15.7 \%$ in 2007 (Anon, 2008b).

Ratnapala, 1979 has studied poverty of rural villages in Sri Lanka and discussed chronic poverty in those villages. One of those villages known as "Wanduressa" which is established by settling down of one of the low caste community in the county named as Rodiya community in 1959 and 1961 was selected for this study with the objective of analyzes the situation of micro level poverty dimensions after 30 years. Further, the study focuses to find out the causes for the changes in poverty over the time.

\section{MATERIALS AND METHODS}

\section{Conceptualization}

Poverty is conceptualized in many ways. In this research poverty has been conceptualized and studied as the low level of satisfaction of the ten basic needs and underutilization of the economic factors.

\section{The Ten Basic Needs}

The "Ten Basic Needs" approach has been used to measure the poverty by measuring the level of satisfaction of the village community for their basic need such as clean and pleasant environment, water, clothing, food, dwellings, health, transport and communication, fuel, education, spiritual and cultural needs (Ratnapala, 1979).

\section{Economic factors}

Financial, human, physical and natural capitals allow communities to have welfare and to follow the customary behaviors of their societies. Poverty exist when the absence or underutilization of these material and non-material resources for the basic satisfaction and well-being of all human beings (Tudawe, 2001). The economic factors which have been studied in this research include financial capital (income indebtedness and savings), human capital (educational, skill and health levels of people), physical capital (housing and mobility) and natural capital (land). 


\section{Location}

Wanduressa is situated about 64 miles away from Colombo (Capital of Sri Lanka) on the Kurunegala-Chilaw road in North-Western Province in Sri Lanka. This village was established by settling down the low cast community named Rodiya community by allotting lands and build houses for them through the Department of Rural Development in 1959 and 1961 under the village reawakening programme.

\section{Sampling methodology}

Stratified random sampling technique was done based on their livelihoods. Six strata were identified as households with several livelihoods, involved mainly in trading (10 HHs), masonry (6 $\mathrm{HHs}$ ), carpentry (5 HHs), government services (10 HHs), rattan production (12 $\mathrm{HHs}$ ) and Agriculture (7 HHs). Total of fifty households (HHs) were selected randomly from each livelihood strata as numbers given in the parenthesis based on the population proportion from the two hundred eleven household in Wanduressa village for the study.

\section{Data collection}

Key person interviews, household survey and focus group discussions have been conducted to collect data. The questionnaire used for the household survey consisted of three major parts. The first part consisted of the questions related to the ten basic needs, second part consisted of questions related to the socio economic data and the third part consisted of the life history tool.

\section{Data Analysis}

Analysis was done as close as possible to the research Ratnapala, 1979 to compare the present situation of satisfaction level for the ten basic needs with the situation in 1979 .

Satisfaction of ten basic needs was measured using a scoring system. According to the scoring system each basic need is awarded 100 marks. Percentage satisfaction was calculated as;

$$
P_{j}=\frac{\sum_{i-1}^{n} x_{i j}}{5000} \times 100
$$

Where,

$x_{i j}=i^{\text {th }}$ Household's satisfaction level of $j^{\text {th }}$ basic need.

$P_{j}=$ Percentage satisfaction of

$j^{\text {th }}$ basic need

$$
\begin{aligned}
& i=1,2, \ldots 50 \quad j=1,2, \ldots, 10 \\
& n=\text { Sample size }
\end{aligned}
$$

\section{Building of Satisfaction level Index for the ten basic needs (SI)}

Satisfaction Index $(S I)$ was developed with the marks given to the household for ten basic needs. Levels of satisfaction were obtained according to the marking scheme asking ten questions from each basic need. Altogether 100 questions were asked to get the overall satisfaction on 10 basic needs (clean and pleasant environment, water, clothing, food, dwellings, health, transport and communication, fuel, education, spiritual and cultural needs). 
Each household's marks were normalized as equation given below.

$$
\frac{x_{i j}-x_{j \min }}{x_{j \max }-x_{j \min }}
$$

Where,

$x_{j \min }=$ Minimum satisfaction value of $j^{\text {th }}$ basic need

$x_{j \max }=$ Maximum satisfaction value of $j^{\text {th }}$ basic need

Principle component analysis was used to reduce the number of correlated variables (variables which are obtained from the questions to evaluate the satisfaction) to few uncorrelated variables. Finally the index was constructed as describe in the equation given below.

$$
S I_{i}=\frac{P C_{1} \lambda_{1}+P C_{2} \lambda_{2}+\ldots P C_{n} \lambda_{n}}{\lambda_{1}+\lambda_{2}+\ldots \lambda_{n}}
$$

Where,

$S I_{i}=i^{\text {th }}$ house hold Satisfaction Index

$\mathrm{PC}_{1}, \mathrm{PC}_{2}, \ldots, \mathrm{PC}_{\mathrm{n}}=$ Principle component values

$\lambda_{1}, \lambda_{2}, \lambda_{\mathrm{n}} \quad=$ Eigen values

\section{Empirical Model}

The empirical model was constructed to find out the relationship between the household's level of satisfaction on the ten basic needs and the socio economic factors.

$$
Y_{i}=\beta_{0}+\beta_{1}(\text { Gen })+\beta_{2}(E d u)+\beta_{3}(\text { Skill })+\beta_{4}(\operatorname{Pri} . O c c)+\beta_{5}(\text { Mo.In })+\beta_{6}(\text { HHsize })+\varepsilon
$$

Categorical data were incorporated as dummy variables as Table 1. Multiple Linear Regression was done to find out the relationship between the household's satisfactions of ten basic needs $(S I)$ and the Socio economic factors of the households as constructed index was normally distributed. Table 01 shows the response $\&$ predictor variables considered for the empirical model. 


\section{RESULTS AND DISCUSSION}

\section{Level of satisfaction of the ten basic needs in community level}

Community level satisfaction for the ten basic needs as a cumulative figure in 2009 is $83.91 \%$. In 1979 it was $29.03 \%$. Therefore over the time the community level satisfaction for the ten basic needs has increased by $54.88 \%$. Table 02 shows the satisfaction level of community for each basic need.

\section{Satisfaction Index (SI) for the ten basic needs of household}

A higher SI score reflects a higher level of satisfaction and vice-versa. Therefore index value provides an assessment of households' satisfaction level for the ten basic needs.

According to the SI values, 92\% households have a satisfaction level greater than 0.5 . That is a good indicator of moving out of the chronic poverty in the study area.

\section{Table 01: Variable defined for the empirical model}

\begin{tabular}{|c|c|c|}
\hline Notation & Variables & Scale \\
\hline $\mathrm{Y}_{\mathrm{i}}$ & Satisfied Index $(\boldsymbol{S I})$ & \\
\hline \multirow[t]{3}{*}{ Edu } & Education level of household & Primary \\
\hline & head & Secondary $\quad-2$ \\
\hline & & No schooling -3 \\
\hline \multirow{3}{*}{ Skill } & Skills of household head & Agriculture -1 \\
\hline & & None-Agriculture - 2 \\
\hline & & Both agriculture \& \\
\hline \multirow[t]{4}{*}{ Pri.Ocu } & Primary occupation of household & Government services-1 \\
\hline & head & Masonry -2 \\
\hline & & Trading -3 \\
\hline & & Weaving rattan products- 4 \\
\hline \multirow[t]{5}{*}{ Income . } & Monthly income of the household & $>20000^{\circ}$ \\
\hline & & $15000-20000-2$ \\
\hline & & $10000-15000-3$ \\
\hline & & $5000-10000-4$ \\
\hline & & $<5000$ \\
\hline HH Size & Household size & Number of members \\
\hline$\beta_{0}$ & Constant & \\
\hline$\beta_{1}-\beta_{6}$ & Coefficients & \\
\hline
\end{tabular}




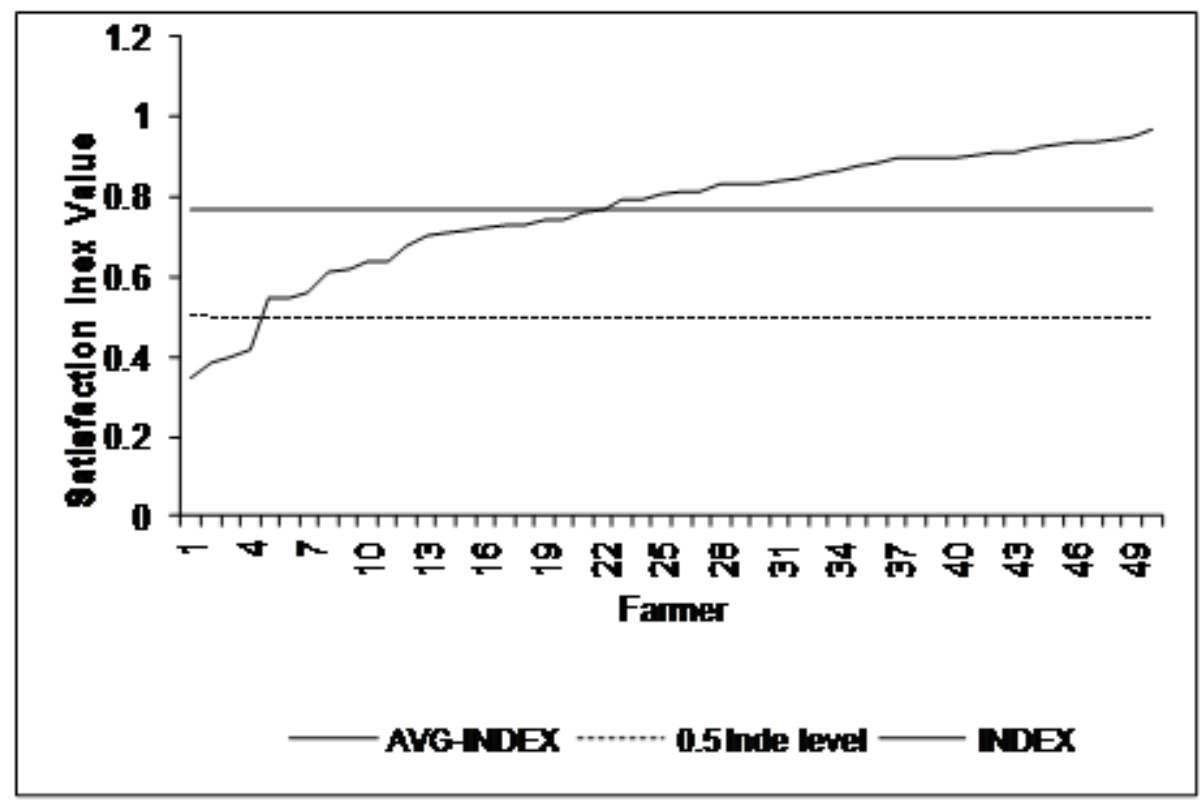

Figure 01: Satisfaction level of individual households for the ten basic needs

Table 02: Community level satisfaction for ten basic needs

\begin{tabular}{cc}
\hline Basic need & Satisfaction level \\
\hline 1. Clean \& pleasant environment & $74.97 \%$ \\
2. Water & $89.6 \%$ \\
3. Clothes & $98.13 \%$ \\
4. Food & $86.18 \%$ \\
5. Shelter & $95 \%$ \\
6. Health & $85 \%$ \\
7. Transport and communication & $81 \%$ \\
8. Fuel & $67.60 \%$ \\
9. Education & $67.01 \%$ \\
10. Spiritual \& cultural & $94.57 \%$ \\
\hline
\end{tabular}


S. A. N. C. Samaraweera and N. R. Abeynayake

\section{Association between SI and socio economic factors}

Table 03 represents the parameters estimated by multiple linear regression. According to results it was identified that the household level satisfactions for the ten basic needs is significantly influenced by income and skills. The households whose income is in the range of Rs. 15000-20000 have highest satisfaction. In same way the households who have skills in the field of non agriculture reported that highest satisfaction than the agriculture.

\section{Economic factors}

Over the time, economic factors of the community have changed. Agricultural involvement, family income per month, adult literacy rate of the community, education levels of adults and health conditions of the village community has increased distinctly and unemployment rate has decreased markedly during the period. Further, results reveal that housing conditions, skills and human resources also have improved in the community (Table 04).

\section{Causes for the change of poverty over the time}

Main income sources have been changed from unsteady sources from to steady sources like Agriculture, Trading, Government job etc. from 1979 to 2009 (Table 4). Therefor the food accessibility has been increased by indicating $40 \%$ increment of food consumption of the households with compare to the statistics in 1979. Apart from that research evident that poverty alleviation programmes such as Janasaviya (1989-1995) and Samurdhi (1995 onwards) has influenced significantly to reduce poverty level of the community.

Table 03. Results of Multiple Linear Regression

\begin{tabular}{lcrrr}
\hline Predictor & Coeff & SE Coeff & \multicolumn{1}{c}{ T } & \multicolumn{1}{c}{ P } \\
\hline Constant & 0.70518 & 0.06779 & 10.4 & 0 \\
Edu_1 & -0.02248 & 0.04871 & -0.46 & 0.647 \\
Edu_2 & 0.07457 & 0.05301 & 1.41 & 0.168 \\
Skill_1 & -0.08939 & 0.07311 & -1.22 & 0.229 \\
Skill_2 & -0.26602 & 0.03474 & -7.66 & $0 *$ \\
Pri_Ocu_2 & 0.04805 & 0.06846 & 0.7 & 0.487 \\
Pri_Ocu_3 & 0.04886 & 0.04001 & 1.22 & 0.23 \\
Income_1 & 0.02588 & 0.06057 & 0.43 & 0.672 \\
Income_2 & 0.16277 & 0.07551 & 2.16 & $0.038^{*}$ \\
Income_3 & 0.07701 & 0.05681 & 1.36 & 0.183 \\
Income_4 & 0.06739 & 0.04834 & 1.39 & 0.171 \\
HH_Size & 0.01222 & 0.01447 & 0.84 & 0.404 \\
\hline
\end{tabular}


Table 04. Comparison of Poverty Dimensions in 1979 and 2009

\begin{tabular}{|c|c|c|}
\hline $\begin{array}{c}\text { Poverty } \\
\text { Dimension }\end{array}$ & 1979 & 2009 \\
\hline 1. Land size & $\begin{array}{l}97 \mathrm{HHs} \text { shared } 150 \text { acres of } \\
\text { land }\end{array}$ & $\begin{array}{l}1 \mathrm{ac}-1 / 2 \mathrm{ac}-40 \% \\
1 / 2 \mathrm{ac}-1 / 8 \mathrm{ac}-8 \% \\
<1 / 8 \text { ac- } 52 \%\end{array}$ \\
\hline $\begin{array}{l}\text { 2. Agricultural } \\
\text { involvement }\end{array}$ & $\begin{array}{l}\text { No any involvement in } \\
\text { agricultural activities }\end{array}$ & $\begin{array}{l}18 \% \text { of the population } \\
\text { involve in the agriculture } \\
\text { (Paddy, Vegetables and } \\
\text { Fruits) }\end{array}$ \\
\hline $\begin{array}{l}\text { 3. Main Income } \\
\text { Source }\end{array}$ & $\begin{array}{l}\text { Rattan production }-71.13 \% \\
\text { Making brooms - } 12.37 \% \text {, } \\
\text { Sanitary labors - } 9.27 \% \\
\text { Begging - 5.15\% } \\
\text { Other businesses }-5.09 \%\end{array}$ & $\begin{array}{l}\text { Agriculture - } 18 \% \\
\text { Rattan products - } 24 \% \\
\text { Trading - } 46 \% \\
\text { Masonry - } 6 \% \\
\text { Government services - } 6 \%\end{array}$ \\
\hline $\begin{array}{l}\text { 4. Family income } \\
\text { per month }\end{array}$ & $\begin{array}{l}\text { Earn less than Rs. 300/- } \\
100 \%\end{array}$ & $\begin{array}{l}<\text { Rs. } 5000-14 \% \\
\text { Rs. } 5000-1000-50 \% \\
\text { Rs.1000-15000- } 18 \% \\
>\text { Rs. } 15000-18 \%\end{array}$ \\
\hline 5. Unemployment & $51.4 \%$ & $35.48 \%$ \\
\hline 6. Houses & $\begin{array}{l}\text { The } 49 \text { houses constructed } \\
\text { by the government were } \\
\text { permanent, other houses } \\
\text { were looked like hovels }\end{array}$ & $\begin{array}{l}\text { Good condition-42\%, } \\
\text { Constructing-56\%, } \\
\text { Dilapidated-2\% }\end{array}$ \\
\hline 7. Vehicles & No & $\begin{array}{l}\text { Bicycle }=18 \% \\
\text { Motorcycle - } 22 \% \\
\text { Three wheeler - } 4 \% \\
\text { Car - } 2 \% \\
\text { Lorry - } 8 \%\end{array}$ \\
\hline 8. Borrowing & No access with banks & $\begin{array}{l}34 \% \text { of } \mathrm{HHs} \text { have taken } \\
\text { bank loans for constructing }\end{array}$ \\
\hline
\end{tabular}




\begin{tabular}{|c|c|c|}
\hline & & $\begin{array}{l}\text { their houses and develop } \\
\text { their livelihoods. }\end{array}$ \\
\hline $\begin{array}{l}\text { 9. Schooling of } \\
\text { adult }\end{array}$ & $\begin{array}{l}95 \% \text { of adult no formal } \\
\text { education. }\end{array}$ & $\begin{array}{l}87.07 \% \text { of adult population } \\
\text { has gone to school. }\end{array}$ \\
\hline $\begin{array}{l}\text { 10.Level of } \\
\text { education of } \\
\text { adults }\end{array}$ & $\begin{array}{l}\text { Few have continued up to } \\
\text { grade } 5\end{array}$ & $\begin{array}{l}\text { Grade } 1-5-47 \% \\
\text { Grade } 6-10-43 \% \\
\text { O/L - } 6 \% \\
\text { A/L - } 3 \% \\
\text { No schooling - } 1 \%\end{array}$ \\
\hline 11. Skills & $\begin{array}{l}\text { Making rattan baskets - } \\
45.16 \% \\
\text { Making ekel brooms - } \\
8.06 \% \\
\text { Making musical } \\
\text { instruments - } 0.6 \% \\
\text { making house hold artistic } \\
\text { items - } 0.6 \% \\
\text { Spinning plates }-2.25 \%\end{array}$ & $\begin{array}{l}\text { Rattan products - } 13.3 \% \\
\text { Trading - } 11.3 \% \\
\text { Agriculture }-1.3 \% \\
\text { Masonry - } 3.3 \% \\
\text { More than one skill - } 22 \%\end{array}$ \\
\hline $\begin{array}{l}\text { 12. Availability of } \\
\text { human } \\
\text { resources }\end{array}$ & $\begin{array}{l}\text { No skilled Carpenters } \\
\text { /masons/ handicraft/ } \\
\text { technical work/ } \\
\text { farmers/traders .etc. }\end{array}$ & $\begin{array}{l}\text { Skilled masons - } 4 \% \\
\text { Farmers }-14.6 \% \\
\text { Traders }-32.5 \%\end{array}$ \\
\hline 13. Nutrition & Prevalence of mal nutrition & $\begin{array}{l}\text { No prevalence of } \\
\text { malnutrition }\end{array}$ \\
\hline
\end{tabular}

Further it is revealed that different types of community level health projects and awareness programmes conducted by the health officers have helped to improve the health conditions of the villagers. Improvement of the educational status (Table 4) has directly influenced the living condition of the community and poverty. Civil war has negatively affected for their poverty elevation preventing rattan weavers to go into forest areas in Pollonnaruwa to obtain rattan. According to the information gathered from the survey it is reported that, $2 \%$ of the households have negatively affected by the war on livelihoods, incomes, clothes and food consumption. 


\section{CONCLUSIONS}

After 30 years of the study of Ratnapala, 1979 and 50 years from the colonization, the level of satisfaction of the ten basic needs has increased from $29.03 \%$ to $83.99 \%$ by $54.88 \%$ and the underutilization of the economic factors has reduced. According to the Satisfaction Index (SI) developed by the study, $92 \%$ households have a satisfaction level greater than 0.5 . Those statistics clearly indicate the moving out of the chronic poverty in the study area.

External changes such as poverty alleviation programmes of the country (e.g. Janasaviya and Samurdhi), NGO funds, and community level awareness programs conducted by the public health officers have facilitated the reduction of the poverty dimensions of the village community over the period under review. Civil war negatively affected on the reduction of poverty.

Households have taken an effort to change their primary occupations, and improve human resources, literacy rates, education levels, skills, dwellings, clothes and health conditions. Through that effort, households have reduced the focus on their inferior communal identity and the separation of the Rodiya community from the mainstream communities.
Even though the education of adult population has increased with respect to the situation of 1979 , still the education levels of the community remain low in comparison to the rest of Sri Lankan population. But a different type of employment skills acquired by the community has facilitated the community to uplift their livelihood condition and it increases the satisfaction of the ten basic needs and utilization of the economic factors. Therefore the entering the mainstream and reducing the chronic poverty has changed via livelihoods rather than via formal education.

Therefore the research reveals that providing incentives and awareness programmes would help to reduce the poverty dimensions. Further the study suggests that anti poverty policies which focus on skill development and empowering chronically poor people towards gainful usage of those skills have a direct impact on reducing poverty.

\section{ACKNOWLEDGEMENTS}

Authors wish to express their gratitude to Centre for Poverty Analysis, Colombo for providing the financial assistance and all other guidance throughout the research period. 


\section{REFFERENCES}

Anon, (2008a). Annual report Central Bank of Sri Lanka.

Anon, (2008b). Poverty indicators, Household income and Expenditure Survey 2006/07. Department of Census and Statistics, Ministry of Financial and Planning, Sri Lanka.

Anon, (2009). Chronic poverty research centre. Available from: http://www.Chronic poverty.org/aboutus/chronicpoverty (Accessed 20 May 2009)

Ratnapala, N. (1979). Rural Poverty in Sri Lanka. NORAD, Colombo.

Tudawe, I. (2001). Chronic poverty and development policy in Sri Lanka: Overview study. Institute of policy studies, Colombo. 